\title{
RELATÓRIO DA COMISSÃO ESPECIAL DO CÓDIGO DE ÉTICA DA ABEn
}

\section{(Criada para apreciar o trabalho da Comissão Especial de Revisão do Código, apresentado por Dra. Haydée G. Dourado)}

A Comissão foi constituída pela Professora Glete de Alcântara, logo após o recebimento do relatório da Dra. Haydée G. Dourado. Deveriam integrá-la os seguintes membros da Diretoria: Glete de de Alcântara, Amália Carvalho, Taka Oguisso e Maria José Schmidt. Não houve convocação para o início dos trabalhos.

Com o falecimento da Presiảente, a Diretoria da ABEn incumbiu a $2 .^{a}$ Vice-Presidente, Amália Carvalho, de com-

\author{
Amália C. Carvalho \\ Ir. Lúcia Cristofolini \\ Maria José Schmidt \\ Taka Oguisso \\ Assessora - Wilma de Carvalho
}

pletar a Comissão e colocá-la em funcionamento. Foi incluído um novo membro, Ir. Lúcia Cristofolini, professora de Ética da EEUSP.

Iniciados os trabalhos, à base do que Dra. Haydée já havia apresentado, a Comissão recorreu à assessoria da Professora Vilma de Carvalho, da EEUFRJ que veio a São Paulo especialmente para esse fim. O resultado está contido no anteprojeto (cópia anexa) já enviado para os membros da Diretoria e para as Seções e Distritos da ABEn.

\section{CÓDIGO DE ÉTICA DA ASSOCIAÇÃO BRASILEIRA DE ENFERMAGEM (ABEn) - ANTE-PROJETO}

\section{PREÂMBULO}

A vida e a saúde situam-se entre os bens supremos do homem.

$\mathrm{O}$ direito à vida e à saúde é universal. A proteção à vida e saúde é o resultado da conjugação de esforços de várias profissões, entre as quais a enfermagem ocupa um lugar de relevância científica e social.
Portanto, no que respeita ao âmbito do exercício profissional, a enfermagem existe e subsiste a serviço do homem e da sociedade.

Neste sentido, o exercício profissional envolve sérias obrigações morais e implicações legais no que concerne a promoção da saúde, prevenção da doença e reabilitação, ao alívio do sofrimento e, também, em última instância, à própria 
justificação da enfermagem como arte assistencial.

Por isso mesmo, a enfermeira, em qualquer situação, responde pessoalmente pela propriedade ou impropriedade de seus atos e no que respeita à esfera de ação dos profissionais de enfermagem, assume a responsabilidade maior quanto à provisão de cuidados de enfermagem a manutenção de elevados padrões de competência profissional.

\section{CÓDIGO}

Art. 1. $0^{\circ}$ A responsabilidade fundamental da enfermeira é prestar assistência específica ao indivíduo, à família e à comunidade, em situações que requerem ações características da enfermagem para proteção e recuperação da saúde, prevenção de doenças, reabilitação de incapacitados, alívio de sofrimento e promoção de ambiente terapêutico. Leva em consideração o diagnóstico e o plano de tratamento médicos.

Art. 2. ${ }^{\circ}$ A enfermeira assume a responsabilidade total pelo exercício de sua profissão. Sua obrigação primeira é para com aqueles a quem presta assistência.

Art. 3. ${ }^{\circ}$ A enfermeira responde pessoalmente pelos atos que pratica no exercíco de sua profissão.

Art. 4..$^{\circ}$ A enfermeira é responsáve] pela definição das condições necessárias à prática da enfermagem, bem como pela iniciativa de solicitar ou tomar providências para que essas condições existam.

Art. 5. ${ }^{\circ}$ A enfermeira respeita a vida humana desde a concepção até a morte. Não coopera em atos em que voluntariamente se atente contra a vida ou que visem a destruição da integridade física ou psíquica do ser humano.

Art. 6. ${ }^{\circ}$ A enfermeira, no exercício de sua profissão, respeita a dignidade e os direitos da pessoa humana, independentemente de quaisquer considerações re-lativas a etnia, nacionalidade, credo político, religião, sexo e condição sócioeconômica.

Art. 7..$^{\circ}$ A enfermeira considera CS valores culturais e as crenças religiosas de seus pacientes e zela para que não lhes falte assistência espiritual.

Art. 8. ${ }^{\circ}$ A enfermeira mantém o sigilo profissional e fundamenta-se no próprio discernimento ao comunicar as informações de que dispõe.

Art. 9. ${ }^{\circ}$ A enfermeira jamais deixa um paciente a seu encargo sem certificar-se de que há provisão para manter a continuidade dos cuidados que lhe são aievidos.

Art. 10 A enfermeira exerce ações apropriadas para salvaguardar o paciente quando sua assistência estiver ameaçada, quer por membros da equipe de saúde, quer por qualquer outra pessoa.

Art. 11 A enfermeira, no desempenho de atividades profissionais, assume responsabilidade pela manutenção de padrões de conduta que refletem crédito para o conceito da profissão.

Art. 12 A enfermeira ao aceitar ou delegar responsabilidade, avalia criteriosamente a sua própria competência, bem como a de todos os membros da equipe de enfermagem. Em situação de extrema urgência aplica tratamentos médicos sem prescrição, relatando-os ao médico assistente o mais breve possível.

Art. 13 A enfermeira assume responsabilidade profissional tanto pela coordenação de todas as atividades que visam o bem estar do paciente, como pela elevação de níveis de desempenho de cuidados de enfermagem, mediante 0 desenvolvimento de programas para aprendizagem contínua. 
Art. 14 A enfermeira compete a responsabilidade principal na determinação e implementação de padrões desejáveis do exercício e do ensino da enfermagem.

Art. 15 A enfermeira coopera com todos os profissionais da equipe de saúde e participa dos planos que visam a distribuição de serviços de assistência à sociedade.

Art. 16 A enfermeira tem direito à justa remuneração, e aceita como retribuição de seus serviços profissionais somente as prestações que lhe foram devidas por contrato escrito.

Art. 17 A enfermeira, por meio de sua atuação nos órgãos de classe, participa na determinação e manutenção de condições justas de trabalho para toda a equipe de enfermagem.

Art. 18 A enfermeira cumpre, com fidelidade, seus deveres cívicos e colabora com os demais cidadãos e profissionais nos programas que se destinam a atender às necessidades de saúde da população, nacional e internacionalmente. 